ISSN 1045-6333

\title{
FEDERAL INTERVENTION TO ENHANCE SHAREHOLDER CHOICE
}

\author{
Lucian Arye Bebchuk \\ Allen Ferrell
}

Discussion Paper No. 332

$08 / 2001$

\author{
Harvard Law School \\ Cambridge, MA 02138
}

The Center for Law, Economics, and Business is supported by a grant from the John M. Olin Foundation.

This paper can be downloaded without charge from:

The Harvard John M. Olin Discussion Paper Series:

http://www.law.harvard.edu/programs/olin_center/ 
August 2001

forthcoming Virginia Law Review, Vol. 87 (2001)

\title{
Federal Intervention to Enhance Shareholder Choice
}

\author{
Lucian A rye Bebchuk and Allen Ferrell**
}

\begin{abstract}
$\underline{\text { Abstract }}$
In a recent article, we have put forward a new approach to takeover law and regulatory competition. We proposed a "choice-enhancing" federal intervention that would provide: (i) an optional body of substantive federal takeover law which shareholders would be able to opt into (or out of) and which would be more hospitable than existing statetakeover law, and (ii) a mandatory process rule that would provide shareholders the right to initiate and adopt, regardless of managers' wishes, proposals for option into (or out of) the federal takeover law. In this paper, we respond to a critiqueof our proposal by Professors Stephen Choi and Andrew Guzman, and we further develop the case for choice-enhancing intervention.
\end{abstract}

JEL Class: G30, H70, K22.

(C)2001 Lucian Bebchuk and Allen Ferrell. All rights reserved.

* William J. Friedman \& A liciaTownsend Friedman Professor of Law, Economics and Finance, $\mathrm{H}$ arvard Law School; Research A ssociate, National Bureau of Economic R esearch.

** A ssistant Professor of Law, Harvard Law School. Wewould like to thank the Harvard Law School John M. Olin Center for Law, Economics and Business for its financial support. Future revisions of this paper will be available for downloading from http:/ / www.law.harvard.edu/ faculty/ bebchuk. 
Federal Intervention to Enhance Shareholder Choice Lucian Arye Bebchuk and Allen Ferrell

In a recent article, $\mathrm{A}$ New Approach to Takeover Law and Regulatory Competition,1 we put forward a novel form of federal intervention in the regulation of takeovers by states. We labeled this approach "choice-enhancing" intervention given its focus on enhancing shareholder choice. Choice-enhancing intervention, we argued, is clearly superior to the current regulatory regime in which states are primarily responsible for takeover regulation.

Choice-enhancing federal intervention has two basic components. First, the federal government would provide a body of takeover regulation that shareholders could opt into (or out of) if they so chose. The second component of choiceenhancing intervention consists of a federal process rule, preempting contrary state law, which would grant to shareholders the right to opt into (or out of) this body of federal takeover regulation, regardless of incumbent managers' preferences. Alternatively, choice-enhancing intervention could also be accomplished through a federal law requiring each state to provide shareholders with the power to initiate and approve, even against the wishes of incumbent managers, opting out of the antitakeover protection provided by state law.

1 Lucian Arye Bebchuk \& Allen Ferrell, A New Approach to Takeover Law and Regulatory Competition, 87 Va. L. Rev. 111 (2001). 
In a response to our article, ${ }^{2}$ Professors Stephen Choi and Andrew Guzman, both strong supporters of unconstrained regulatory competition in prior work, ${ }^{3}$ offer a critique of our proposal. Our response is organized as follows. Part I will defend our view as to the value of the mandatory federal process rule. Part II will then defend our arguments concerning the value of a federal optional regime. Finally, Part III will conclude with a remark on how the introduction of choiceenhancing federal intervention should trigger a reassessment of the positions taken by supporters of unconstrained regulatory competition.

\section{The Mandatory Federal Process Rule}

The mandatory process rule is aimed at addressing distortions that occur in the decisionmaking process governing whether corporations reincorporate to another state and are thereby subject to a different state's corporate law. The problem, which we identified and analyzed in earlier work, 4 is that under the law of every

2 Stephen J. Choi \& A ndrew T. Guzman, Choice and Federal Intervention in Corporate Law, 89 Va. L. Rev. __ (2001).

${ }_{3}$ Choi and Guzman madean important contribution to the unconstrained regulatory competition view by bringing it to bear on theinternational sphere. SeeStephen J. Choi \& Andrew T. Guzman, Portable Reciprocity: Rethinking the International Reach of Securities Regulation, 71 S. Cal. L. Rev. 903 (1998).

4 SeeLucian AryeBebchuk \& Allen Ferrell, Federal ismand Corporate Law: The Raceto Protect M anagers from Takeovers, 99 Colum. L. Rev. 1168 (1999); Lucian A rye Bebchuk, Federalism and the Corporation: The Desirable Limits on StateCompetition in Corporate Law, $105 \mathrm{H}$ arv. L. Rev. 1435 (1992). For an analysis of this problem using a formal model of state competition see Oren Bargil, Michal Barzuza, and Lucian A rye Bebchuk, The Market for Corporate Law (working paper, 2001). 
state managers have a veto over whether a reincorporation will occur or not. ${ }^{5}$ If managers' and shareholders' interests substantially diverge, which they sometimes will in the context of takeover regulation (among other contexts), then a distortion in the decisionmaking process arises. The mandatory federal process rule that we have put forward, which ensures that shareholders have the ultimate power over whether reincorporation occurs, is an effective and straightforward means of removing this distortion.

This process rule, a crucial component of choice-enhancing intervention, is very difficult for supporters of state competition, the traditional critics of any federal regulation, to oppose. If shareholders wish to move to another state, why not let them? In light of this dilemma it is not surprising that Choi and Guzman state that a "shareholder opt-in rule may have some merits." ${ }^{6}$ But they remain critical of the idea.

They express several objections to our analysis. First, they raise reasons why shareholder voting will not work well. Second, they infer that something must be wrong with it from the fact that this process rule has not al ready been adopted. Their reservations are misplaced.

5 This is becausereincorporations under statelaw haveto beinitiated by thecompany's board of directors.

${ }_{6}$ Choi \& Guzman, supra note 2, at 39. 


\section{A. Problems with Shareholder V oting}

\section{Shareholder A pathy and D eference to $M$ anagers}

Choi and Guzman begin their critique focusing on problems with shareholder voting by highlighting the problems of collective action and rational apathy affecting shareholder voting. ${ }^{7}$ As a result of these problems, they reason, shareholders might not have an incentive to participate in a vote or might simply vote according to managers' recommended position.

We agree that shareholder voting might be imperfect in this way. Indeed, the ability of managers to get shareholders to vote in favor of management positions was used by one of us in earlier work as the basis for arguing for the importance of various midstream problems in corporate decisionmaking. ${ }^{8}$ But the problems of collective action and rational apathy at most suggest that shareholders will not always vote to reincorporate even when this would be beneficial. This in no way implies, however, that we should deny shareholders the power to initiate and approve reincorporations. If a majority of shareholders have in fact voted in favor of reincorporation (overcoming collective action and rational apathy problems) there is no reason to ignore their decision. To the contrary, if shareholders vote in favor of reincorporation, despite the problems that depress voting against management

7 See id. at 47.

8 See Lucian Arye Bebchuk, Limiting Contractual Freedom in Corporate Law: The Desi rable Constraints on Charter A mendments, 102 Harv. L. Rev. 1820 (1989). 
(or voting at all), such a vote suggests that a reincorporation really would be in the interests of shareholders.

Consider the case in which, despite the recommendations of management, a majority of shareholders vote to have the company move to a regime more hospitable to takeovers. To argue that it would be optimal not to have such a shift in regulatory regimes, it is not sufficient to claim that shareholders in other cases are inclined to vote with management. Nor is it satisfactory to argue that the shareholders voting in favor of a move might be imperfectly informed. Rational but imperfectly informed shareholders will take into account their having less information than management and will vote in favor of the move only if they conclude that, all things considered-including both the fact that management has more information and the possibility that it might have self-serving motivations-they will be better off on an expected value basis by moving.

Finally, it is worth noting that there is a tension between Choi and Guzman's support of unconstrained regulatory competition and their reliance on a paternalistic view that shareholders do not know what is good for them. Shareholders' knowing what is good for them, after all, is the very foundation for the position of supporters of regulatory competition that such competition works well.

\section{Blackmail by Large Shareholders}

The second problem with voting that Choi and Guzman identify is that shareholder power to initiate and approve reincorporations would enable large 
shareholders to use their votes as leverage in extracting benefits from management. ${ }^{9}$ Their argument focuses on large shareholders who are not in control and whose ability to extract preferential treatment from managers depends on their power vis-àvis managers. The ability to initiate and push for reincorporations, they fear, will lead such large shareholders to threaten to move to a shareholder value-decreasing regime unless they are paid off by management.

We do not find this scenario to be of any significant concern. Most importantly, the mandatory federal process rule would not increase in any significant way the power that large shareholders have. There are already important shareholder votes that take place. Most obviously, there is shareholder election of directors, which is presumably the most important vote to management. The threat to initiate a vote to move to a shareholder value-decreasing regime would likely be considerably less powerful vis-àvis managers compared with the threat to vote against them in the election of directors or even to run a proxy contest against them. In addition, large shareholders can threaten to vote against managers in votes on fundamental changes (such as on charter amendments). We do not know of any substantial evidence that large outside shareholders are able to extract significant benefits from management due to the existence of such votes. Moreover, we are unaware of any argument that such a concern makes it worthwhile to eliminate any of these votes.

${ }_{9}$ Choi \& Guzman, supra note2, at 7, 47-48. 
The particular threat of large shareholders that Choi and Guzman hypothesize —voting for a move to a shareholder value-decreasing regime—is unlikely to be particularly threatening to managers. If the move is significantly shareholder value-decreasing, it is doubtful that the large shareholder will be able to get support for the move from a majority of shareholders. Given the point raised by Choi and Guzman earlier that shareholders tend to vote with management, a vote by them against management would be especially unlikely when such a vote would not benefit shareholders but rather would considerably harm them. Furthermore, there are credibility problems with such a threat since carrying it out would not be in the large shareholder's interest, as it has a significant financial stake in the company.

\section{Voting Cannot Eliminate All M anagerial O pportunism}

The third problem that Choi and Guzman identify with shareholder voting is that voting does not eliminate the potential for managerial qpportunism. ${ }^{10} \mathrm{We}$ agree, but do not see how this suggests that shareholders wishing to reincorporate should not have their wishes honored. The federal process rule will have served its purpose if it increases the likelihood that shareholders will be able to subject their company to the best legal regime possible. Even under such a regime, given problems of observability and verifiability, managerial opportunism would, alas, still be with us. But this does not imply that increasing shareholder choice, and 
thereby improving the chances that companies will be subject to the rules that would best combat managerial opportunism, is not a worthwhile idea.

\section{Cycling}

Lastly, Choi and Guzman claim that shareholder voting might be subject to vote cycling. ${ }^{11}$ Consider a hypothetical scenario in which the current state of incorporation A is disfavored by a majority of the shareholders to that of another state B, that $B$ is disfavored by (another) majority to state $C$, and that, finally, state $C$ is disfavored to that of state A. As a result, there might fail to be one state that would always be chosen by shareholders. Instead, there could be a "cycling" effect with different states being preferred by shareholders in different votes. In this case, so the argument goes, allowing shareholder initiation might lead to a cycle in which each year the company will move with no final destination.

Again, we do not think this is an important concern. ${ }^{12}$ To begin with, we doubt that the phenomenon of cycling is likely to arise in the corporate context. Shareholder interests are likely to be far more homogenous, given the common shareholder interest in maximizing share value, than the preferences of populations in which cycling might be an important phenomenon. Second, and most important, even assuming that there are sometimes occasions of a cycle of three

10 ld. at $47-48$.

11 Id. at $49-50$.

${ }_{12}$ For a more complete analysis of why cycling concerns do not provide a basis for denying sharehol ders the power to initiate certain important corporate decisions, see 
top choices, none of which dominates the other two, the most significant problem is the possibility that shareholders, due to the managerial veto over reincorporations, might be stuck with a regime inferior to all those in the cycle of top choices. Without a mandatory federal process rule, managers would be able to keep their company in state $D$, even if it is worse than any of the regimes of states A, B, or C. Finally, assuming that a cycle of top choices arises, once we ensure that management is unable to keep the company in a regime which is dominated by any of the choices belonging to the cycle of top choices, there are ways to provide management with some agenda-setting power that would enable it to serve as a tiebreaker among the choices belonging to the top cycle (states A , B, and C in our hypothet(al).13

\section{B. If It's Good, Why D oesn't It Exist A Iready?}

Choi and Guzman also use another argument that is often used against proposals for mandatory rules, whatever their content. We can refer to this as the "Panglossian argument." We live in the best of all possible worlds because the market ensures that this is so. ${ }^{14}$ In this Panglossian view, there can never be a reason for a mandatory rule. If it is good, it is going to be provided anyway. And if it is not being provided, it must be because it is not good.

Lucian Bebchuk, The All ocation of Power Between Managersand Shareholders (working paper, 2001).

13 See id. 
Specifically, Choi and Guzman make two claims. First, they argue that, if an arrangement allowing shareholders to initiate reincorporations is beneficial, companies would have already adopted it in their charter provisions. ${ }^{15}$ To start with, as we indicated in our paper, state law has long had mandatory rules that require managers to initiate reincorporations. Reincorporations take the form of mergers, and mergers must be initiated by a board proposal. Companies cannot opt out of this rule through charter provisions.

Furthermore, even if theoretically companies could do it via charter provision, it would hardly be possible for any company acting alone to realize the benefits of a mandatory process rule, which would apply to companies across the board. Suppose that a company adopted an initial charter provision according to which shareholders could by vote opt into the takeover law of a federal optional regime or that of some other state. This would not work by itself unless federal law provided such a regime or the other state was willing to apply its regime only for the takeover matters of this company.

The benefits of a mandatory federal process rule are benefits that result from having a number of companies subject to such a rule, thereby providing states with better incentives to provide a regime conducive to shareholder interests. The point of choice-enhancing federal intervention is improving regulatory competi-

${ }_{14}$ We do not mean to imply by this that Choi and Guzman are wild-eyed optimists. As the old saw goes, optimists believe that welivein the best of all possibleworlds, while pessimists are afraid this is true.

${ }_{15}$ Choi and Guzman, supra note 2, at 43-44. 
tion between states. In short, this is a case in which network externalities appear to be quite large, which impedes the ability of companies to get the benefit of such an arrangement through private action.

Second, Choi and Guzman argue that, if a mandatory process rule were beneficial, then states seeking to attract initial incorporations would have an incentive to adopt it.16 It is worthwhile to note that they do not claim that adoption of a mandatory process rule would enable a state to attract publicly traded companies located in other states. But existing publicly traded companies-not initial public offerings ("IPOs")-are the main source of incorporations at any point of time. Confining oneself to only initial incorporations, as we explained in our paper, is not a promising strategy.

Our view, which we briefly discussed in our paper, is that the regulatory competition process, even seen in its best light, is far too imperfect to provide any basis for inferring that any given existing feature of it is optimal. Indeed, the same reason why the regulatory competition process might currently produce imperfect substantive rules also indicates that it might produce imperfect rules with respect to how the reincorporation process is structured.

It is interesting to observe that Choi and Guzman themselves, in another part of their essay, reject the ability to make the type of inferences under consideration. Choi and Guzman suggest that it might be optimal to allow switching not only to an optional federal regime or to the regimes of other states but also to regimes of- 
fered by "private suppliers." 17 They then raise the question that they ask of choiceenhancing federal intervention: If this is so good, why haven't Delaware and other states allowed companies to switch to such private regimes? They say that “[s]everal responses are possible,"18 and include among them (i) the argument made in our paper that the ability of the dominant state to imitate is bound to chill innovation, and (ii) the interests that state regulators (and, we might add, local bar interests) might have in retaining control over their state's corporate law.

Thus, Choi and Guzman believe that, due to the identified imperfections of state competition, the absence of a process rule allowing switching to private suppliers does not imply that allowing such switching might not be beneficial. They should find equally acceptable our position that the absence of a state rule allowing reincorporation by shareholder vote does not provide a basis for concluding that such a rule would not be beneficial.

\section{The Optional Federal Takeover Regime}

Choi and Guzman doubt whether the provision of an optional federal takeover regime, assuming a mandatory federal process rule was already in place, is needed. ${ }^{19}$ We in fact raised the possibility of only adopting the process rule without a concomitant federal takeover regime in our original paper and indicated that this would go a long way towards satisfying our concerns with the current struc-

16 Id. at 39.

17 Id. at 16-19.

18 Id. at 20. 
ture of state competition. ${ }^{20} \mathrm{As}$ a result of the mandatory process rule, states would have strengthened incentives to offer shareholder wealth-maximizing legal regimes. There are several reasons, nevertheless, why we believe that an optional federal takeover regime would in fact be worthwhile.

A mandatory process rule that allows switching into the takeover law of other states, standing alone, might not be sufficient because the competition between states for corporate charters is imperfect. The market for corporate law is one in which the dominant supplier, Delaware, has some built-in advantages. As a result, states might not have adequate incentives to develop and offer a competing takeover regime. A state considering competing with Delaware might worry that Delaware would match any successful corporate innovations and thereby continue to retain its existing incorporations. Thus, such a state might worry that it would merely serve as a stalking horse to force Delaware to make changes in its corporate law.

Because of the imperfections in state competition, our view is that states might not have sufficient incentives to mount a challenge and offer an alternative takeover regime even with a mandatory process rule in place. For this reason we think that it might be worthwhile for the federal government to offer an optional federal regime that is more hospitable to takeovers. Choi and Guzman accept that state

19 Id. at $50-51$.

20 Bebchuk \& Ferrell, supra note 1, at 154. 
competition might be imperfect, ${ }^{21}$ but argue that the stalking horse problem and poor incentives to maximize shareholder welfare might equally afflict federal regulators. 22

\section{A. Federal Regulators' Incentives}

Choi and Guzman ignore, however, the possibility that federal and state officials' objective functions-thestandard by which success is measured-might well be different. Montana citizens will derive little benefit from improving the takeover rules governing out-of-state companies, the overwhelming majority of whose shareholders are from other states. Accordingly, if Montana officials were to put forward an alternative regime whose main consequence would be to push Delaware to adopt similar rules, Montana citizens are not much better off. ${ }^{23}$ Thus, to the extent that the political process somehow aligns the interests of Montana officials with those of Montana citizens, those officials would not have a significant incentive to adopt such rules.

In contrast, the interests of U.S. citizens as a whole would very much be served by improving the takeover rules governing U.S. corporations. For U.S. citizens as a

${ }_{21}$ Choi \& Guzman, supra note 2, at 20.

22 Id. at 27-30.

${ }_{23}$ Even if some companies were to opt-into M ontana's regime, this would havelimited upside. Most states, other than Delaware, garner only limited revenues as a result of incorporations. See Ehud Kamar \& M arcel Kahan, PriceDiscrimination in theMarketfor Corporate Law (working paper, 2001). 
whole, the adoption of a federal regime that would improve the takeover regulation to which U.S. companies are subject would be a significant benefit, regardless of whether this was accomplished by pushing Delaware to improve upon its own rules or by reincorporations into the federal optional regime. Accordingly, federal officials would have an incentive, not present at the state level, to put forward a shareholder friendly regime, even if there were no guarantee of garnering large fees.

\section{B. Lobbying by $M$ anagers at the Federal Level}

Building on the work of Professor Roberta Romano, ${ }^{24}$ Choi and Guzman are quite concerned about lobbying by special interest groups at the federal level.25 Indeed, they think that lobbying by managers seeking antitakeover protection might be especially powerful at the federal level. In our view, however, this concern does not favor unconstrained regulatory competition over choice-enhancing intervention.

24 See generally Roberta Romano, The Genius of American Corporate Law (1993) (arguing against mandatory federal intervention, in part, on political economy grounds). Professor Romano also stresses that the empirical literature, and in particular reincorporation event studies, establishes that statecompetition benefits investors. We respond to this argument in a forthcoming work, which shows that the empirical evidence cannot bereliably interpreted as favoring state competition. See Lucian A rye Bebchuk \& Allen Ferrell, Does theEvidenceFavor StateCompetition in CorporateLaw? (working paper, 2001).

${ }_{25}$ Choi \& Guzman, supra note 2, at 25-32. Romano has also criticized uson thegrounds that we do not give adequate attention to this issue. See Roberta Romano, The N eed for Competition in International Securities Regulation 187-94 (working paper, 2001). 
To begin with, it is worthwhile to emphasize that state competition, in addition to whatever distortions arise from lobbying, has another problem. As we explained, managers' power over incorporation decisions by itself, without any lobbying by managers, provides states with incentives to offer antitakeover protection. That is, even if managers were to exert no effort whatsoever in lobbying, the competition among states as it currently operates would produce a strong antitakeover bias. This distorting force does not operate at the federal level.

Furthermore, choice-enhancing intervention would by its very operation undermine any lobbying by managers intended to secure takeover law that is more protective than shareholders' desire. Given the presence of the mandatory process rule, which would enable shareholders to opt into and out of regulatory regimes, adopting takeover rules that would be excessively protective in any given regime (including the federal optional takeover regime) would not help managers much, as shareholders would be able to opt out of this regime.

\section{The Slippery Slope A rgument}

Choice-enhancing federal intervention is intended to represent a desirable change in how states compete with each other from the standpoint of those who accept the problems we identified with regulatory competition in the takeover area, but without the baggage of imposing mandatory rules. Nevertheless, Choi and Guzman's views of choice-enhancing intervention are shaped by the dark shadow cast by mandatory federal rules. They raise the concern that an optional 
federal takeover law would open the door to mandatory federal rules. ${ }^{26}$ We suspect that other commentators might be similarly influenced.

It is important to recognize the sweeping, uncabined scope of this objection. This type of concern can al ways be raised with respect to any proposal for changes at the federal level, however meritorious the changes are on their own terms. The response can always be: Sure, your proposal might be beneficial, but federal regulators might go off and do something really harmful if your proposal is considered or adopted. We believe it is valuable to consider, and press for, regulatory changes that have promise in the absence of a more concrete, particularized indication that the proposal is likely to backfire in this way.

\section{A Iternative V ersions of ChoiceEnhancing Intervention}

Finally, it is worth emphasizing that the focus of our work is on the value of federal intervention in enhancing shareholder choice, not on the particulars of an optional federal takeover regime. This is the point that we wish to stress for those who find the idea of having a federal optional takeover regime unattractive or costly or difficult for whatever reason.

For example, one alternative version of choice-enhancing federal intervention would bethe adoption of a federal law requiring states that adopt antitakeover arrangements to enable shareholders to opt out—via a shareholder vote-of those antitakeover arrangements. Given that poison pills are currently a critical element

${ }_{26}$ Choi \& Guzman, supra note 2, at 30-31. 
of the antitakeover protection accorded by states to managers, shareholder choice could be enhanced by adopting a federal law that requires states to allow shareholders to adopt binding bylaws that would prohibit (or limit) the use of poison pills. Although commentators have supported giving shareholders the power to adopt such bylaws, we believe that states are unlikely to do so by themselves. Such a federal law would be a simple and direct way of enhancing shareholder choice.

\section{RETHIN KING BY SUPPORTERS OF STATE COMPETITION}

One goal of our paper was to confront those who oppose federal intervention with the need to rethink their position. We sought to demonstrate that there are ways to improve the current process of regulatory competition—by changing the ground rules of the competition and by having the federal government offer an alternative optional regime-without the need for mandatory federal rules. The desirability of shareholder choice does not imply that federal law should automatically assume a completely passive role.

We read the Choi and Guzman essay as suggesting that the hope for such reconsideration by those who support regulatory competition is not unfounded. In their piece, Choi and Guzman seem to accept that managerial control over reincorporation decisions might be undesirable and that the institution of shareholder unilateral voting to opt into another takeover regime or another corporate law re- 
gime altogether may "improve state competition." 27 They also accept that problems of imperfect competition might prevent states from offering a competitive challenge to the dominant incumbent, Delaware.28

To be sure, these concessions are all put in a very tentative and cautious way. Moreover, Choi and Guzman seek to downplay the significance of their openness to some of our main points by saying that, since we are seeking to expand shareholder choice, we are willing "to work within the state competition framework."29 One could of course say that by recognizing imperfections in regulatory competition and the potential benefit of federal intervention, Choi and Guzman are willing "to work within the critique of state competition framework." The question of labeling is, of course, ultimately unimportant. What is important to us is that, as Choi and Guzman have started to do, others with strong sentiments in favor of regulatory competition will start recognizing the problems of state competition and consider the new form of federal intervention, which focuses on expanding shareholder choice, that we have identified.

27 Id. at 60.

$28 \mathrm{Id}$. at 20.

29 Id. at 61. 